\title{
Indonesia - GAM Peace Process Reflection on Turkey - PKK conflict
}

\author{
Afriandha Fakhri \\ FISIP UIN Syarif Hidayatullah Jakarta Jakarta, Indonesia \\ Dr. Badrus Sholeh \\ FISIP UIN Syarif Hidayatullah Jakarta Jakarta, Indonesia
}

\begin{abstract}
In the history of humanity, conflicts have become an integral part. In every process of human development, there will be conflicts. Hence, it is required to gain more knowledge on conflicts. Time after time, humans are learning on how to manage conflict, by examining its cause and find the solutions. In the $21^{\text {st }}$ century, conflicts are still prevalent throughout the globe. This paper focuses on the Indonesia-GAM conflict and its reflection to TurkeyPKK conflict. By reflecting the Indonesia-GAM conflict, this work looks for a solution that can be implemented to resolve the Turkey-PKK conflict. The research was carried out by collecting the data from the primary and secondary source of information which were obtained through interview, literature study, and online resources.
\end{abstract}

Keywords: conflict, turkey, GAM, peace, Indonesia.

\section{INTRODUCTION}

Conflict that happened between a state and a non-state actor can be classified as a struggle by a state to maintain its national security, since national security is essential in order to maintain the existence of a state. Regarding the concept of security in individual, national, and international level, Barry Buzan mentioned that:

National security is particularly central because states dominate many of the conditions that determine security at the other two levels.... [1]

This implies the importance of security at the national level, which makes the term "national security" relevant. To associate states and non-state groups with the concept of national security, one can look at the correlation between them. Peter Hough stated that "a major issue of global security since the late $1960 \mathrm{~s}$, that of political violence waged by non-state actors" [2]. Separatist groups are classified as non-state actors since it does not represent a state and instead, pose a threat to a state by waging violence in a political motive, which makes the concept of national security becomes more relevant with the topic of separatism. On the other hand, the states, especially in the $21^{\text {st }}$ century, have to have awareness and understanding of a threat posed by the violent non-state actors [3].

Partiya Karkeren Kurdistane, or Kurdistan Workers' Party is a political organization that aims at the liberation of Kurdish people from the oppression by the Turkish government. This organization was formed in 1973 as a movement for the Kurds because they were assuming that their right to self-determination was taken away by the government. PKK is the answer to this problem [4]. Years passed, this movement was gaining more and more support from the Kurds, making it stronger. PKK's struggle against Turkish government was marked by their aggressive behavior. They often use armed attack to articulate their struggle. The year 1984 marked the first armed struggle of PKK, as they attacked military facilities in Eruh and Semdili [4].

The armed resistance carried out by PKK continued until the 21 st century. They implemented their struggle by numerous attacks of bombing and direct assault to military officials such as the bombing of Istanbul in 2003 and the bombing of Ankara in 2007 [5]. As the clashes continued, both party tried to carry out peace efforts by talks and discussion. In 2013, Turkish president, Erdogan announced that there is a peace talk going on between PKK and the government of Turkey [6]. The peace process included cease-fire and the withdrawal of PKK fighters from Turkey to Iraq [7].

This peace process went well at first, but in 2015 , the good relations that have been built by both parties collapsed before reaching the final solution to the long-lasting conflict. The event of Suruc bombing and siege of Kobani marked the end of the peace process between PKK and Turkish 
government. Until now, there is not yet a final solution that can bring peace to PKK and the Turkish government.

A solution to a conflict can be found by finding a similar conflict which has been ended peacefully with a final solution. Regarding the rebellion issue, Turkey that faces PKK as the enemy is identical to the conflict between Indonesia and Gerakan Aceh Merdeka (Free Aceh Movement or GAM) in Indonesia. PKK and GAM have some similarities, as the two organizations are political organizations that demand independence from the ruling government and use armed resistance as their way of struggle. The difference between the two is that PKK is purely based on ethnic struggle, while GAM is based on ethnic and religion struggle.

\section{CONFLICT PROCESS}

Indonesia has gone through the same position as Turkey regarding the rebellion and uprising by an armed group. For thirty years, Indonesia has gone through a serious conflict with GAM. The root of GAM insurgency can be tracked back into DI/TII era which also took arms against the Indonesian government in a separatist insurgency. This uprising had successfully suppressed as DI/TII stopped its insurgency. Then, the separatist was successfully merged into Indonesia by a special autonomy to Aceh [8]. The new form of insurgency emerged in 1976 as people of Aceh realized that the central government overexploited Aceh's natural resource. This exploitation followed by an unequal profit given to the people of Aceh. The autonomy given by the central government to the people of Aceh are nothing but a symbol rather than a substantial one [8].

This new emerged movement tried to make a new independent state, separated from Indonesia. This movement focused on the freedom of Aceh; this is why they named it Free Aceh Movement or Gerakan Aceh Merdeka. The government of Indonesia immediately labeled this organization as a separatist movement and declared this movement as a threat to the national security of Indonesia. Efforts were made by the Indonesian government to eradicate this movement, such as direct military operations known as DOM (Daerah Operasi Militer) or Military Operations Area. It made Aceh as a subject of martial law which applied twice, in 1990 during the presidency of Soeharto and in 2003 under Megawati's leadership [9].

This method did not result well, as the movement did not go down. Instead, it made GAM gained more sympathy from people of Aceh. The assassinations that happen during the implementation of this method made the locals think of it as an ethnic cleansing or genocide act [8]. Then, under the leadership of the Susilo Bambang Yudhoyono, the government of Indonesia changed the method to solve this rebellion problem by changing the policy regarding the conflict in Aceh. Indonesian government started to open communication with GAM. Indonesian government implemented an integrational approach which paired the military actions with diplomatic efforts. In the peace process between the two parties, Vice President Jusuf Kalla had a central role in the dialogues and talks between the two [10].

The peace process between the Indonesian government and GAM stepped into the next stage when Martti Ahtisaari, the former president of Finland, acted as the mediator in dialogues and talks between the two. The appointment of Ahtisaari as the mediator based on his success in ending the Kosovo conflict in 1999 as a representative of the European Union, in which he also played a significant role [10]. This mediation process ended with both sides agreed to make peace. The agreement of peace between the two is written in Helsinki Agreement. In this agreement, Aceh is given the special autonomy which included authority within its public sectors. People of Aceh is given the opportunity to establish Aceh-based political party as a form of political participation. This agreement mentioned that every individual who have participated in GAM activities will be granted with amnesty. After the conflict ended, every ex-GAM who have renounced their Indonesian citizenship will have the rights to regain it. In other words, people who participated in GAM will reintegrate to the Republic of Indonesia as its citizen [11].

In Turkey-PKK conflict, one state solution is the only way to solve the conflict. This is due to the chance of Turkey attacking the new-formed Kurdistan if they successfully received its independence from the Turkish which will probably cause a bigger and longer conflict. Hence, in order to end the conflict, Turkish government must find a way to prevent the Kurds to actually separate themselves from Turkey.

\section{ALTERNATIVE AND SOLUTIONS.}

The key to solving the conflict in Aceh and Kurdistan is the by utilizing the integrational approach. The multiethnic condition in Indonesia and Turkey has to be viewed as a diversity, and every single ethnic within the state should be recognized. By doing this, integration can easily be done. In the case of conflict in Aceh, both parties 
were willing to be integrated into one country, which is Indonesia. In the case of Turkey-PKK conflict, Turkish government must be able to be an "umbrella" which accommodates every group in its country. The solution to this conflict must not be a homogenous solution. This is because homogenization is commonly attributed to the forced acculturation. Besides that, homogenization can also result in wiping out an entire ethnic which is known as ethnic cleansing or genocide. Such occurrence can happen when there is no recognition from one ethnic to another. The ethnic which hold the majority wants to keep its identity as the identity of the whole nation. Hence, denying the identity of the other ethnic groups. On the other hand, the integrational approach aims to provide a welfare equity and equal opportunity for every ethnic group. This method will make Kurdistan go through a transformation. The PKK, similar to GAM, cannot manage to undergo the same conflict forever. In the end, PKK will adopt a more realistic approach, which involving negotiation and reconciliation with the official government [12].

Since the conflict in Aceh and Kurdistan is similar, the solution to the conflict can also be similar. In other words, the answer to Aceh conflict can also be utilized on Turkey-PKK conflict. The government of Turkey should adopt the solution made by Indonesian government regarding the conflict in Aceh. A rebellion group will stop rebelling if their interest is fulfilled. The target is to fulfill its demand and to fulfil the government's interest as well. The Turkish government should recognize the identity of Kurdish people by not trying to assimilate Kurdish and the Turkish forcibly. Then, the government can give a special autonomy to the people of Kurdistan. The central government will hold some authority, while the autonomous government will hold some as well. The division of authority will be the subject of the negotiation between two parties. This policy can eliminate Kurdish rebellion against the government because their right to self-determination has finally fulfilled by the government, so there will be no more separatist resistance against the government.

When the peace has already restored, Turkish government should implement a policy that allows Kurdish ex-combatant to merge into Turkey. There should not be any criminalization against the ex-combatant of PKK. By applying this policy, the process of integration will be much smoother and natural. The official government will get more support from the ex-combatants as they will be willing to cooperate with the official authority of the country. After that, people of Kurdistan should be given the opportunity to establish a political party of their own. By doing this, Kurdish people will be actively participating in politic, so they will be able to voice their opinion towards the government.

\section{CONCLUSION}

In conclusion, the conflict between Turkish government and the PKK can be solved by imitating the process done by Indonesian government when dealing with GAM. Peace is the only solution to any conflict since the zero-sum game cannot be implemented to end a conflict. Indonesian government had proven that the zerosum game is impossible. The military action, such martial law implemented in Aceh, was not successful at all. In the end, peace solution is the best solution to the conflict. The peace process can be done in any way, mediation by a strong third party can be a very effective way in doing so. The process did not end with an agreement only; actions must be taken after it, in order to merge the ex-separatist into the state. 


\section{Reference}

[1] Buzan, Barry. 2007. People, States and Fear: Agenda for International Security Studies in the Post-Cold War Era, Colchester: ECPR Press.

[2] Hough, Peter. 2004. Understanding Global Security New York: Routledge.

[3] Williams, Phil. 2008. "Violent Non-state Actors and National and international Security", International Relations and Security Network.

[4] Ocalan, Abdullah, 2009. War and Peace in Kurdistan. Cologne: International Initiative.

[5] "Timeline: PKK Attacks in Turkey, Al-Jazeera." 2011. Accessed 26 Agustus 2017 (http://www.aljazeera.com/news/europe/2011/10/201 $\underline{11019164441520246 . \mathrm{html})}$

[6] Mesut Yegen. 2015. "The Kurdish Process in Turkey: Genesis, Evolution, and Prospects" Istanbul Policy Center.
[7] "PKK Sets Date for Withdrawal from Turkey." 2013. Aljazeera. Accessed 26 Agustus 2017 (http://www.aljazeera.com/news/europe/2013/04/201 $\underline{342513922579836 . h t m l)}$

[8] Suadi Zainal. 2016. "Transformasi Konflik Aceh dan Relasi Sosial-Politik di Era Desentralisasi." MASYARAKAT: Jurnal Sosiologi 21(1).

[9] "Conflict and Peacemaking in Aceh: A Chronology." Worldwatch Institute. Accessed 29 Agustus 2017 (http://www.worldwatch.org/node/3929)

[10] Aspinall, Edward, 2005. The Helsinki Agreement: a More Promising Basis for Peace in Aceh? Washington: East-West Center Washington.

[11] Memorandum of Understanding Between The Government of The Republic of Indonesia and The Free Aceh Movement

[12] Machmudi, Yon. Interview by Author. Voice Recording. Depok, July 13th, 2017. 